University at Buffalo School of Law

Digital Commons @ University at Buffalo School of Law

$1-1-1989$

\title{
The Legal Community and the Transformation of Disputes: The Settlement of Injunction Actions
}

James B. Atleson

University at Buffalo School of Law

Follow this and additional works at: https://digitalcommons.law.buffalo.edu/journal_articles

Part of the Law and Society Commons, Litigation Commons, and the Torts Commons

\section{Recommended Citation}

James B. Atleson, The Legal Community and the Transformation of Disputes: The Settlement of Injunction Actions, 23 Law \& Soc'y Rev. 41 (1989).

Available at: https://digitalcommons.law.buffalo.edu/journal_articles/803

(C) 1989 Law and Society Association. Reproduced with permission.

\section{IN COPYRIGHT}

This Article is brought to you for free and open access by the Faculty Scholarship at Digital Commons @ University at Buffalo School of Law. It has been accepted for inclusion in Journal Articles by an authorized administrator of Digital Commons @ University at Buffalo School of Law. For more information, please contact lawscholar@buffalo.edu. 


\title{
THE LEGAL COMMUNITY AND THE TRANSFORMATION OF DISPUTES: THE SETTLEMENT OF INJUNCTION ACTIONS
}

\author{
JAMES B. ATLESON
}

\begin{abstract}
Lawyers in cases involving injunctions against picketing represent clients in situations of great immediacy. A significant number of injunction actions are settled with reductions in picketing despite a seemingly restrictive statute and a highly organized workforce. This study of legal culture examines the role of lawyers in striving to create predictability, especially in regard to judges and the police, and in transforming conflicts of value into disputes over interests that can be resolved without resort to formal adjudication.
\end{abstract}

\section{INTRODUCTION}

Injunctions against labor picketing are a highly emotive and important area of American labor history and union ideology. Since the 1930s, federal and state laws have explicitly protected strikes and picketing. ${ }^{1}$ New York's anti-injunction statute (N.Y. LAB. LAW $\S 807$ (McKinney, 1977)) appears even more protective than the federal Norris-LaGuardia Act (29 U.S.C. § 101-115), and the state has a long tradition of unionism and a highly organized work force. Yet, when injunctions against picketing are sought in

A version of this essay was presented at the Annual Meeting of the Law and Society Association in Chicago in June 1986 and at a faculty forum at Rutgers-Newark Law School in May 1987.

Research was supported by grants from the National Science Foundation and from the State University of New York at Buffalo.

The author wishes to thank David Engel, Frank Munger, Fred Konefsky, Bliss Cartwright, Eileen Silverstein, William Forbath, Clyde Summers, Lynn Mather, and anonymous reviewers for their helpful and insightful comments. I would especially like to thank David Engel, Frank Munger, and Fred Konefsky for their constant encouragement for a project so different from my normal ventures. I also wish to thank Andrew Lipkind for his wonderfully imaginative and resourceful research assistance. Dianne Avery and Richard Troll also provided valuable research assistance.

1 Restrictions on picketing, however, were explicitly imposed by the TaftHartley Amendments (61 Stat. 136 (1947)), and courts read in restrictions on the right to strike even prior to this statute (see generally Atleson, 1983). Courts have not accorded labor speech such as picketing the same degree of protection as political or even commercial speech (see Atleson, 1985b: 856-62; Pope, 1984; Yale Law Journal, 1982).

LAW \& SOCIETY REVIEW, Volume 23, Number 1 (1989) 
Buffalo, relief is obtained with considerable frequency. Attempts to obtain injunctions generally result in privately negotiated settlements and less frequently in formal judicial orders to which the union has consented. These settlements or injunctions generally restrict the scope or scale of picketing. Appeals from judicial orders are rare, and thus there are few appellate decisions that clarify the scope of the statute.

The question is why, given a seemingly unambiguous anti-injunction statute, injunction actions are both brought and settled. To study the initiation and resolution of these disputes, I interviewed and examined the files of union and labor attorneys in Buffalo. The result is an inquiry into legal culture, its effects on the handling of disputes, and the way in which lawyers act to make behavior predictable. Attention is directed primarily to the process by which disputes of value are settled and, secondarily, to the role of formal law in that process.

The assumption that a strike and its accompanying pressure (or the threat of a strike) make collective bargaining work underlies the explicit protection of concerted action in the National Labor Relations Act (NLRA) of 1935 (ch. 372, § 1, 49 Stat. 499 (codified as amended at 29 U.S.C. $\S 141$ et seq. 1974)). In a sense, as the Supreme Court said in another context, collective action is part and parcel of the collective bargaining process (National Labor Relations Board (NLRB) v. Insurance Agents International Union 361 U.S. 478 (1960)). The picket line is a pressure device used to resolve an economic or contractual dispute. When the employer seeks legal assistance, the legal basis for its plea for relief is not the economic harm the picketing has caused, but rather the claim that collective activity has exceeded the bounds of propriety, a boundary defined by formal law. Although the employer in essence asserts rights based upon property, it stresses community interests because injunctions are permitted to deter violence and to maintain public order. Yet the employer obviously also wishes to use law to affect the balance of economic forces, that is, to make the law a participant in the dispute. ${ }^{2}$

Despite the strong economic interests of employers and the traditional values of unions, injunction actions are often settled by private agreement or by consent to a judicial order. One explanation for settlement in this area might be that the statute, either in language or as administered by courts, is not as clear as first appears. Indeed, state trial and appellate court decisions in New York show a willingness to grant injunctions in highly questionable situations despite the seemingly restrictive anti-injunction stat-

2 The use of law in this situation seems not to be motivated by a desire to strengthen fragile bonds or to renegotiate an ongoing relationship (Yngvesson, 1985). Nevertheless, litigation in industrial relations is not inconsistent with the continuation of the relationship as revealed by the frequent use of labor arbitration. 
ute. Whatever problems of ambiguity may lie in the statute or decisions, however, unions often decline to assert federal as well as state statutory rights to engage in concerted activity. ${ }^{3}$ The legality of picketing is rarely litigated at all. Settlements are reached prior to, and indeed instead of, a judicial hearing.

Unions and employers are "repeat players" (RP), legal actors who possess the motivation and ability to use the legal system to pursue their long-term interests. According to Galanter (1974: 110-113), legal actions between repeat players should not be commonplace. Because these parties "play with each other repeatedly, the expectation of continued mutually beneficial interaction would give rise to informal bilateral controls" (ibid., p. 110. See also Macaulay, 1963: 64). When litigation is initiated, however, Galanter (1974: 112) theorizes that one might expect "heavy expenditure on rule-development, many appeals, and rapid and elaborate development of the doctrinal law." Moreover, one would also expect "practice to be closely articulated to the resulting rules" (ibid., p. 113). Yet, contrary to the Galanter model, the picketing-injunction situation does not result in either prolonged litigation or clear rule development.

This study of injunction cases suggests several explanations for the unexpected pattern. First, although lawyers perceive the statute to be clear, judicial behavior is not viewed as predictable (Macaulay, 1966). 4 Second, the time and expense involved in litigation militate against zealous advocacy (See Macaulay, 1963; Aspin, 1970. See also Weiler, 1983). Finally, settlement is possible because a range of indeterminancy exists between the parties' interests despite the fact that initially none seems to exist. The legal choice is actually broader than merely a judicial decision to grant or refuse to grant an injunction, for judges traditionally have assumed the power to grant partial injunctions, that is, to grant orders that bar violence and that carefully specify the maximum

3 See, for instance, Capital Newspapers Division-The Hearst Corp. v. Chester W. Vanderbilt, 44 Misc. 2d 542 (1964); Triangle Finishing Corp. v. Textile Workers Union of America, 145 N.Y.S.2d 614 (1955). One explanation for the settlement of injunction actions, which may seem generous in light of applicable law, may be provided by Ross (1970). In his study involving the insurance industry, Ross found that the generosity of insurance companies in settling claims was based primarily upon intraorganizational dynamics. Faced with conflicting orders to settle expeditiously but economically, insurance adjusters act in accordance with the order to close quickly, which can be more easily measured. The actions of unions, however, do not seem to be affected by conflicting orders, nor are they bombarded by injunction threats. As will be subsequently noted, however, intra-institutional concerns are relevant to the common settlement of injunction actions.

4 Unlike the situation involved in Macaulay's study, the primary uncertainty present here involves broad judicial discretion more than ambiguous substantive law. Mnookin and Kornhauser (1979) suggest that vague legal standards affect negotiations and relative bargaining power. They focus upon strategic advantage and do not discuss the possibility that lawyers will try to deal with uncertainty by creating their own standards. 
number or location of pickets per entrance. The focus of most injunction cases ultimately, if not initially, is on the number and location of picketers.

\section{RESEARCH METHODOLOGY}

\section{A. The Cases}

I studied attempts by employers in Buffalo to secure injunctions against picketing between 1974 and 1979. Injunction cases were identified through interviews with union and employer attorneys ${ }^{5}$ and by examining the special term calendars of the state supreme court records in Buffalo (the trial court in New York's judicial system $)^{6}$ as well as the labor union and strike files of two Buffalo newspapers. ${ }^{7}$ This search, aided by the recollections of attorneys, yielded twenty-four attempts in the five-year period. ${ }^{8}$ There was no accurate way to determine the number of situations in which picketing occurred during the period.

Once cases were found, the primary sources of data were the files and the memories of employer and union attorneys. ${ }^{9}$ Twelve employer attorneys and nine union lawyers were interviewed. ${ }^{10} \mathrm{~A}$ number of attorneys had worked on more than one case, and opposing attorneys in all but two cases were interviewed. Interviews varied widely in length, from one to three hours, depending upon the lawyer's recollections, the number of cases the lawyer had been involved in, and the normal interruptions of law practice. Appellate court reports were also reviewed to provide information on the incidence of appeals, the scope of judicial discretion permitted, and the success of union appeals of injunctions.

5 These interviews produced 8 cases not identified from other sources.

6 A search of court calendars disclosed 9 cases. State supreme court files were also searched, but the filing process proved too inefficient for systematic research. Supreme court records in Buffalo are filed by defendant's name, and labor or picketing cases are not filed separately. Commonly, an officer of the defendant union, rather than the union itself, is listed as the first-named defendant, making research abnormally time-consuming. None of the cases discovered from the newspaper files was listed, but several new cases were discovered. Many injunction petitions are not filed, however. Moreover, many injunction actions that terminate in a privately negotiated settlement are not formally filed at all. Indeed, in some cases petitions were sent to union lawyers prior to filing with the court. Should a settlement occur at this point, attorneys need not file the papers or pay the ten dollar fee.

7 The papers were the Buffalo News and the now-defunct Buffalo Courier Express. This search yielded 7 cases.

8 There is no reason to believe that this period was atypical for labormanagement relations.

9 Attorneys were uniformly helpful and cooperative. Without their generous assistance this study could not have been conducted. The only condition requested was one of confidentiality, an understandable and reasonable request that has been fully respected.

10 The number of labor law attorneys, especially union side, in any community is generally small. Union representation in Buffalo, for instance, is almost completely centered in 4 firms. 


\section{B. The Interviews}

Lawyers who had sought injunctions were asked to describe the factors they used in determining whether to seek an injunction; the predictability of the substantive law and range of possible outcomes, at least compared with other areas of practice; and how their views of the law and possible outcomes affect the decision to file an injunction petition or to negotiate a settlement as well as the framing of the content of a settlement.

Union attorneys were asked to describe the decision to negotiate or to insist on a hearing, and the extent to which substantive legal ambiguity, broad judicial discretion, or other constraints affect the decision to negotiate, the content of any settlement, or the decision to appeal or to forgo an appeal. They were also asked whether union clients perceive negotiation as a surrender of statutory rights and, if so, why the statutory right to a hearing or to an appeal is routinely waived. Finally, they were asked about the extent to which intra-union political or institutional considerations affect the union's behavior.

\section{AN OVERVIEW OF APPLICABLE LAW}

The general contours of the law regulating the granting of injunctions can easily be described, although the details are quite complex. The Norris-LaGuardia Act of 1932 generally barred federal courts from granting injunctions in "labor disputes," except when picketing involved violence. Similar statutes were subsequently enacted in many states, and New York's version, section 807 of the state's labor law (N.Y. LAB. LAw $\$ 807$ (McKinney, 1977)), mirrors the federal statute. ${ }^{11}$

11 The substantive right to strike and to picket was first given explicit federal protection in the National Labor Relations Act of 1935. Certain types of strikes and picketing, however, were subsequently barred by legislation in 1947 and 1959. This federal protection supersedes, or preempts, state regulation in cases falling within the broad commerce clause jurisdiction of the $\mathrm{Na}$ tional Labor Relations Act except for a narrow range of situations where the state's interest is deemed to be critical, most commonly when violence has occurred or is threatened. See Allan-Bradly Local No. IIII v. Wisconsin Employment Relations Board (WERB), 315 U.S. 740 (1942); United Auto Workers (UAW) v. WERB, 336 U.S. 245 (1949); UAW v. WERB, 351 U.S. 266 (1956); Youngdahl v. Rainfair, Inc., 355 U.S. 131 (1957). The degree of violence cannot, perhaps, be clearly expressed, possibly because our definition is affected by our underlying values. In Youngdahl, for instance, the U.S. Supreme Court permitted the state court to enjoin mass name calling and abusive language as well as threats. The issue, said the Court, is "whether or not the conduct and language of the strikers were likely to cause physical violence" (355 U.S. at 138 (1957) (emphasis added). It held that "words can readily be so coupled with conduct as to provoke violence" (ibid.). Nevertheless, the injunction could only be as broad as the conduct deemed wrongful.

Beyond enjoining any conduct or language that might be an "incitement to violence," therefore, the state court could not restrict peaceful picketing. A complete prohibition against picketing could only be sustained if a "pattern of violence was established which would inevitably reappear in the event picketing was later resumed" (ibid. at 139). The tests above contain critical empirical 
The explicit purpose of these statutes was to free union collective action from judicial restraints that were often perceived to be arbitrary and based on no guidelines other than the social and economic views of individual judges. ${ }^{12}$ Moreover, these statutes were designed to remove the policy-making function of judges, for the courts' standards involved a determination of the degree of "legitimate" or "justifiable" interest the union may have had for its actions (Atleson, 1985a).

Prior to the passage of this legislation, judges espoused the view that injunctions merely returned the situation to the status quo. In reality, however, an injunction can effectively determine the outcome of dispute. The timing of collective action is often critical, and the energy involved in gearing up for such a move is difficult to revive if collective action is initially barred.

The New York statute bars injunctions in labor disputes except in seemingly narrow circumstances. ${ }^{13}$ Like its federal predecessor, the statute prohibits an injunction except after both holding a formal hearing ${ }^{14}$ and making detailed findings of fact specified in the statute.

The statute also mandates certain procedures for the hearing (N.Y. LAB. LAW $\S 807-1,2$ (McKinney, 1977)). The plaintiff-employer is required to plead and prove compliance with all legal obligations and to allege and prove that it made every reasonable effort to settle the dispute by negotiation, mediation or arbitration (ibid., § 807-4). The plaintiff must also file a minimum undertaking of one thousand dollars in case of expense or damage

and behavioral assumptions on which data do not exist, and the context and pressure atmosphere of an injunction proceeding may not be conducive to careful determination of these issues.

Both the reported cases and the union lawyers interviewed in this study indicated that the injunction cases focus almost exclusively on section 807 of the state law. Preemption issues are rarely if ever raised. Given that it is a state judge who would determine whether violence was threatened or existed sufficient to fall within the exception to preemption, the viability of this doctrine in state court is questionable in any event. As Sovern (1963: 548) has noted, a state judge's decision "about the point at which picketing becomes violent or massed may obviously differ from the decision the NLRB would have reached on the same facts."

12 The problems with unregulated judicial activism are noted in the classic book by Felix Frankfurter and Nathan Greene, The Labor Injunction (1930). This work was basically a brief for the passage of the Norris-LaGuardia Act. See also Bernstein, 1960: 391-415; Gregory, 1961: 158-199.

13 New York judicial decisions under section 807 generally assert that "Section 807 of the Labor Law, modeled after the Federal Norris-LaGuardia Act, imposes stricter limitations than previously existed on the issuance of injunctions in any case involving or growing out of a labor dispute" (Waldbaum, Inc., v. United Farm Workers, AFL-CIO, 87 Misc. 2d 267, 269 (1976).

14 Injunction proceedings in New York begin with the filing of a motion to show cause why an injunction should not issue. Lawyers stated that this motion, filed with supporting affidavits usually alleging picket line or other violence, is always granted. A hearing may then be held to determine whether an injunction should issue. 
caused by the improvident or improper issuance of an injunction (ibid. § 807-3).

The statute limits the scope of relief that can be granted. Because courts can only enjoin violent activity, the legal inquiry is whether, assuming violence is found, the violent behavior can be separated from allowable picketing. In making this determination, courts may permit the picketing but restrict the number and location of picketers.

Most importantly, three critical findings are necessary before an injunction may issue. The first is a finding that "unlawful acts have or a breach of any contract not contrary to public policy has been threatened or committed and that such acts or breach will be executed or continued unless restrained" (ibid., § 807-1(a)). New York courts have interpreted this requirement with considerable flexibility. In Triangle Finishing Corp. v. Textile Workers Union of America (145 N.Y.S.2d 614, 616 (1955)), Justice Alisi said that "picketing to be peaceful must be free, not only of violence, but also free of any intimidation, free of any form of physical obstruction or interference." This passage, frequently quoted by New York courts, provides the justification for an injunction for any judge who believes that picketing is inherently coercive. ${ }^{15}$

While courts exercise considerable latitude in deciding whether collective action threatens violence, the second critical finding required by the statute, that "substantial and irreparable injury to complainant's property will follow unless the relief requested is granted" (N.Y. LAB. LAw $\S$ 807-1(b) (McKinney, 1977)), appears to allow less discretion. In fact, however, the courts frequently focus not on the damage the violent or mass picketing was or will be responsible for but on the economic damage the labor dispute has caused as a whole. In Capital Newspapers DivisionThe Hearst Corp. v. Chester W. Vanderbilt (44 Misc. 2d 542 (1964)), for instance, the court found section 807-1(b) was satisfied because

the drastic decline in circulation which, to a great extent, has been caused by the picketing activities adequately demonstrates that substantial and irreparable injury to complainant's property will follow unless the relief requested is granted.

Such a focus renders the "substantial and irreparable injury" requirement a minor hurdle if the union's activity is at all effective.

Finally, before granting equitable relief, a court must find that

15 Various state court decisions illustrate how easily "violent" or "mass" picketing is found. See Busch Jewelry Co., Inc., v. United Retail Employees' Union, Local 680, 281 N.Y. 150 (1939); B. C. Manufacturing Co., Inc., v. Louis Reiff, 14 Misc. $2 d 37$ (1958); Bridge Hardware Co., Inc., v. Hyman Horowitz, 22 Misc. 2d 914 (1949). Often the evidence relied on is extremely slight or, at most, mildly provocative. Many states allow ex parte proceedings to form the only basis for the injunction. See, generally, Aaron, 1964. The experience in New York in the years after that state passed an anti-injunction statute is discussed in Galenson and Spector, 1942. See also Seidenberg, 1953. 
"the public officers charged with the duty to protect complainant's property have failed or are unable to furnish adequate protection" (N.Y. LAB. LAW § 807-1(e) (McKinney, 1977)). Yet after pointing out that all the section 807 requirements tend to be found as a matter of course, New York Jurisprudence dryly comments that this is particularly true "with regard to the inability of public officers to protect the plaintiff's property." In Capital Newspapers (at 546), for instance, the court admitted there was no evidence presented as to the capability of the police department to furnish adequate protection, but the court nevertheless held that section 807-1(e) was satisfied because

there exists doubt in the mind of the court whether any municipal police force could effectively carry out its normal duties while at the same time constantly provide sufficient protection to insure the maintenance of order and protection to the public as well as the plaintiff in a heavily picketed area. The court senses the legislative intent and finds that the additional burden placed upon the police officers charged with the duty as set forth in the statute cannot be met.

Thus, while a literal reading of each requirement of section 807 would make it extremely difficult to obtain any injunctive relief, the decisions have often required merely a pro forma allegation and finding, especially where "violent" union activity has been alleged to exist. In many instances the section's requirements are recited and, without explanation, deemed satisfied. In view of the language employed, many parts of section 807 evidently invite value judgments and conclusions that lie totally within the discretion of the trial court.

Clearly, despite an apparently strong anti-injunction statute, courts maintain considerable discretion in determining whether to grant an injunction (see, e.g., Bridge Hardware Co., Inc. v. Hyman Horowitz, 22 Misc. 2d 914 (1949)). Nevertheless, despite the ambiguities in the judges' views of violence, the employers' claims in the cases studied involved allegations of unambiguously violent acts by picketers. Union lawyers often stated that their adversaries would not have filed for an injunction unless violence within the statute existed, and they may have had sufficient information to verify the allegations in employer affidavits. The conclusion, as will be subsequently set out, is that claims and responses by both sets of lawyers, at least in the lawyer community in Buffalo, are affected by an interest in being viewed as responsible.

\section{THE MIDDLE GROUND}

In the twenty-four cases studied in which employers sought injunctions against union picketing, the parties consented to judicial orders in nine cases, formal injunctions without consent were granted in four cases, and private agreements (stipulations) were 
reached in two cases. ${ }^{16}$ Thus, restrictions on picketing resulted in the majority of cases (15 out of 24), and unions agreed to restrictions in eleven of those fifteen cases. In some "consent" cases, however, the union consented based upon the perceived likelihood that some kind of formal injunction would be otherwise forthcoming.

The typical judicial order bars acts that would be violations of the criminal law; prohibits interference with nonstrikers, customers, and other persons; and generally restricts the number and location of picketers. An excerpt from a typical order follows:

ORDERED, that the defendants and their respective agents, servants, employees, attorneys, and all persons whomsoever acting in their behalf or in conjunction with them cease and desist:

1. From stationing more than ten (10) pickets at each gate of the plaintiff's said plant;

2. From interfering or blocking any automobile, truck, or pedestrian traffic on the roadway leading to the plaintiff's said plant and from interfering or blocking any sidewalk or driveway leading to said plant;

3. From forming a picket line in front of the plaintiff's said plant in which the pickets walk or stand closer than five (5) feet from one another;

4. From trespassing or entering upon the premises or place of business of plaintiff and from threatening, intimidating, or turning aside against their will those who go or would go to and from said place of business of the plaintiff;

5. From intimidating the employees of the plaintiff herein, working for said plaintiff, and from otherwise resorting to force, threats, or intimidation to compel said employees to leave the employ of said plaintiff or to compel said employees to refrain from working for said plaintiff;

6. From interfering or blocking directly or indirectly any rail traffic into plaintiff's plant; . . . .

The parties often agree to limit picketing without a formal judicial order. Unlike formal orders, such private agreements or "stipulations" do not subject the violator to the contempt power of the court if they are breached. One attorney described a stipulation as "basically a private contract between the parties." Should a violation occur, however, the employer could decide to refile its injunction request. Lawyers stated that judges sometimes signed the agreement, although they acknowledged that such action had no legal significance, that is, the signing did not convert the private agreement into a formal order. Stipulations look much like formal orders, indicating the extent to which private settlement language mirrors that of the courts.

Constraints on both employer and union attorneys help to explain why a settlement agreement often occurs without the need

16 Five cases were adjourned; the other 4 were discontinued or denied. 
for a court order and why orders are granted with the consent of the parties without the statutory requirement of a hearing. Settlement saves both time and expense, critical factors when judicial action is often seen as unpredictable. Although the attorneys expressed concern about unpredictable judicial behavior, some union attorneys said that they were inclined to settle because they believed their employer counterparts would not have sought injunction unless there was a reasonable basis for the employer's request. Thus, in most cases attorneys for both sides believed that there was sufficient evidence of violence to waive the statutory bar to injunctions.

Indeed, a substantial degree of coordination and cooperation among attorneys is revealed in these cases. As repeat players in a relatively small community, the possibilities for detecting overstatement and irresponsibility may increase the extent to which labor lawyers can rely on adversary representation. In addition, in some cases an injunction settlement may be perceived to have institutional value for the union. Satisfied with its show of strength, the union may not view a limit on the number of picketers as either a waiver of principle or a serious economic restriction. Moreover, the injunction may actually be useful to control rankand-file militants or to halt picketing that the union feels is unwise but that it cannot politically be seen to oppose.

For both sets of attorneys, settlement is aided because a "middle ground" exists between the attempt to bar all picketing and the union's customary desire to avoid any judicial restriction. The compromise position is often a settlement or judicial order that limits the number or the location of picketers or both. ${ }^{17}$ The privately reached settlements mirror formal orders granted by courts. These compromises represent real concessions by each party,

17 The following excerpt is an example of the great particularity to be found in these orders:

F. Having any pickets or other person at or near plaintiff's ... plant [is prohibited] except as follows:

1. During the hours of 7:00 a.m. $-4: 30$ p.m. no more than three pickets may patrol or be in the vicinity of the entrance of plaintiff's plant at ... [address]; no more than two pickets may patrol or be in the vicinity of the westerly ... entrance to plaintiff's facility, and no more than two additional persons covered by this order may be present in or about the vicinity of the strikers' van or other vehicle.

a. Union shall be allowed 10 minutes to change shifts at 7:00 a.m.; 12:00 noon; and 4:30 p.m. During this period, no more than an additional five persons covered by this order may report to the strikers' van. At 4:00 p.m., an additional two persons may report to the strikers' van. The limitation on the total number of picketers shall apply throughout the shift changes.

2. During all other hours, no more than three persons covered by this order may be present in or about the vicinity of plaintiff's facility or the strikers' van or other vehicle; and no more than two picketers may patrol.

3. Each picket shall be separated from every other picket by a distance of at least six feet at all times. 
within a legal system that literally protects peaceful picketing and restricts the injunctive power of courts.

The norms of dispute resolution are thus not the product of formal adjudication. Although judges are indeed involved, as either motivators of settlement or somewhat unpredictable adjudicators, the process of dispute resolution emerges primarily as a creation of the parties and their attorneys.

\section{THE CONTEXT FOR SETTLEMENT}

This study primarily focuses upon the assumptions and behavior of lawyers. The behavior of lawyers, however, cannot be totally understood without analyzing how they perceive the role of other actors who can affect the outcome of injunction proceedings. For instance, the police enforce orders and injunctions, and their testimony is critical should any case reach a hearing. In addition, the trial court judge plays a crucial role both as mediator and as formal adjudicator. Interviews with lawyers reveal a range of ambivalence about the judges, their objectivity, their knowledge, and their public posture. Finally, lawyers may be influenced by the potential role of the appellate courts. The following discussion is based primarily upon the perceptions of the lawyers who were interviewed and does not include the perceptions of others, such as the clients.

\section{A. Public Order and the Role of the Police}

To avoid the statutory proscriptions on the granting of injunctions, courts must conclude that police are unable to keep order (e.g., to restrict criminal and civil wrongs or to protect "ingress and egress"). The New York statute requires that the court find that the "public officers charged with the duty to protect complainant's property have failed or are unable to furnish adequate protection" (N.Y. LAB. LAW § 807-1(e) (McKinney 1977)).

Petitions for injunctions, then, must make allegations similar to the following:

TENTH: Plaintiff has consistently applied to police officials by numerous telephone calls from the ... [date] to the present date and by daily personal visits, for protection against the unlawful acts of the union and the other defendants, but such protection against the activities set out herein has been inadequate in as much as such public officials are unable to furnish in full the protection necessary to plaintiff against the commission of such unlawful acts.

The court's determination that the police are unable to maintain order is almost wholly based upon the testimony of police officers. Such testimony is only received if a statutory hearing is held, 
although attorneys may seek the views of the police before reaching a settlement. ${ }^{18}$

The role of the police also leads to the questioning of the rational decision model. The settlement-or injunction-often serves to empower the police. If a hearing does occur, the statute necessitates police testimony that they are unable to secure order. If the police view such an admission as a failure in law enforcement, they might understandably be reluctant to provide testimony to support an injunction. In fact, however, attorneys reported that the police were willing to offer support for injunctive relief, characterizing the problem not as a failure of law enforcement but rather as a product of manpower constraints. As one company lawyer explained,

The company called the police, who did a good job when there; but the police were not there all the time. The local police captain asked the company to seek an injunction after a while, before he'd send his men in. . . . In the hearing, ... . [the union attorney] pressed the police inadequacy requirement of section 807, over ... . [the company's] argument that the police were unable to maintain order. The judge asked for police testimony. The deputy commissioner who was monitoring the strike said that after two days of large-scale picketing, his manpower was too thin in the rest of the precinct. By his testimony, the police representative in effect asked the parties to limit the number of pickets.

An injunction provides the police with important legal support in a sensitive situation. Police are convinced that injunctions empower them to enforce the law, even though they technically only bar violations of existing law. The injunctions legitimize enforcement efforts by police who might otherwise be disinclined to enforce existing law on picketers.

Except for limitations on the scope and location of picketing, the primary content of a judicial order is the proscription of already unlawful action. Private stipulations will bar similar behavior. Although they are only private agreements, stipulations are obviously created in the "shadow of the law" (or the shadow of a judge).

A company lawyer stated that he sought a "judge-signed paper" to give to the union, the company, and the police. The prevalent police feeling, he explained, was to refrain from moving without a court order: "In a strike situation, you don't enforce the law without an injunction."19 Indeed, at the few judicial hearings that

18 It is not clear how often union attorneys seek the views of the police prior to reaching a settlement.

19 The lawyer had not learned this from the police but rather from his clients, who deal with the police in these cases. With the possible exception of the Buffalo Police Department, an injunction generally helps motivate police to act. 
were held, police officials were said to state routinely that they would not try to provide a pathway into a plant without an injunction. The judicial empowerment, apparently, does matter.

For instance, in one of the more explosive cases involving a bus company strike, the company alleged a good deal of violence and even the union attorney conceded in his interview that an injunction could probably be obtained. The company alleged destruction of property by picketers, including the use of "Polish cannons" (gas bombs made of beer cans filled with golf balls), and possession of baseball bats. The company also sought a ban on what its attorney referred to as libelous and slanderous press statements. The attorney alleged that the union had been stopping occupied buses, removing the management drivers, and leaving the: passengers to sit without anyone to drive the buses:

There was use of home-made cannons, sabotage to vehicles, removal of fan belts, creating a dangerous situation in which the riding public could have been killed. Most of these incidents were off the picket line, but there were incidents on the line too: picketers got riotous, blocked passage, threatened management drivers of vehicles.

The company lawyer was certain he could have obtained an injunction had a full trial been held, and he believed he had witnesses for every allegation. "Police reports showed the futility of law enforcement efforts. They showed up often but never made any arrests." The inference could then be drawn that police were unable to control the scene. Yet the police chief told him that the "police don't want to favor one side over the other, and don't want to appear anti-union." Thus, they were "reluctant to go in without an injunction."

Sometimes police reluctance existed even after a judicial order was issued, as one company attorney noted:

The police like to have an injunction. But this is the only case I've ever had where the . . . county sheriffs did not ever try to keep the plant open, even after the injunction was issued: We had to call the judge and get him after the sheriff's department.

Thus the injunction provides evidence that the police are acting neutrally. In addition, an injunction has a significant effect on those to whom it applies. A company lawyer stated:

What is the purpose of enjoining already illegal conduct? It is to give the police additional "meat" when making arrests. Contempt is a real threat: Clarity of details gives the police more feeling of authority to back up their actions. The most important reason . . . is to have a subconscious effect on troublemakers, that they'll be held in contempt for these specific acts as well as for any "illegal acts."

This may be why judges occasionally signed stipulations that were clearly not formal orders. 
Injunctions, then, have a power beyond the mere assertion by the police that certain actions are unlawful, and police armed with an injunction may face less hostility and opposition from picketers. As attorneys noted, injunctions "cool down" tense situations, and they do so "immediately." Such a perception may explain why judges sometimes sign stipulations, an act whose effect is only "psychological." According to a union attorney,

The stipulated order was not an injunction. The company could not have sued upon it nor gotten a contempt ruling. It was merely an agreement. The judge's signature is mainly psychological.

The power of injunctions is perhaps implicitly recognized by the injunctions and agreements themselves, which, after all, enjoin actions that are already unlawful. It is also possible that the injunction is perceived as narrowing the range of discretion that the police possess to enforce formal law. Moreover, injunctions also serve a function for union officials. One company attorney explained that

enjoining conduct already illegal-this should not be necessary, but it is. As a practical and political matter, most union leaders won't control membership without being able to tell the pickets that it's per order of the court. It is politically better for the union officer to "blame" restrictions on the court.

Despite police reluctance to act decisively without an order, some union attorneys perceived the police with suspicion while others felt that police testimony was generally fair. Some union attorneys-as well as the company lawyer quoted below-mentioned that police are also unionized or come from working class families.

The police inadequacy requirement of section 807 was typically dealt with in ... . [this case]. [The judge] . . . required police testimony. The police are in a bad position. They know the workers they have to deal with. The police don't want to hurt other unions-after all, the police and labor are both union-oriented. So the police will sit pat while incidents happen, but on the stand will testify that they can handle it, but not much longer, or manpower will be drained if they have to keep handling it. In ... . [this case] the police said that in order to control the scenes, they'd need more police cars and chiefs. This was not possible-it would drain normal operations.

Another company lawyer presented a similar view. He noted that the local police were often reluctant to get involved and that they usually preferred to have an injunction in hand before acting. He mused that the police often have unionist feelings and that they will not intervene against another union without being forced to do so by court order. This lawyer recalled one incident in which the police were standing outside the plant gate. One of the pickets 
started to throw rocks at the police. A policeman took a rock and threw it back inside the gate, saying something to the effect that " 'if you want to throw rocks, throw it at them, but not at us!" "

The "realism" of the police is indicated in the following newspaper report (Buffalo News, October 26, 1983: 17) quoting the Buffalo chief of police in regard to name-calling on picket lines:

Deputy Police Commissioner John B. Myers told the Buffalo News that the police receive a report almost every day about reported picket line violence. However, he said, the amount of violence is below that of most industrial strikes.

He said that the police are not concerned with namecalling. "If someone comes through a picket line, I doubt very much that the pickets are going to say 'good morning,'" he said.

Commissioner Myers said the police force is impartial in the strike. "We're going to stay that way," he said.

\section{B. The Judges}

The judges are key actors in injunction actions. As in most actions brought to the court, judges in injunction cases encourage settlement. Attorneys in these cases, however, reported that many judges were particularly disinclined to take formal action. This reluctance to act may be fueled by the sensitivity of the judges to their position as elected officials in an active union city, but the judges also may recognize the incentives for parties with a continuing relationship to resolve their own differences. Many of the attorneys described the substantial efforts of the judges to facilitate settlement or at least to avoid issuing a formal decision. A union attorney noted that while in court "No testimony was taken. The two sides spent six hours in chambers, working out a settlement, with Judge . . . sitting back passively. The judge was not in the room most of the time, in fact." The company attorney in the same case explained that ". . . the judge's role was to sit in initially and then suggest that the parties work it out."

Most attorneys know the local state court judges even though the bulk of their litigation is conducted before federal judges, the NLRB, or private labor arbitrators. In general, lawyers reported that they have little control over the particular state court judge they face. Actions are initiated by a show-cause order. Lawyers did have some control over the particular judge who responded to the show-cause request, but all attorneys stated that these requests are never denied. ${ }^{20}$ As a company attorney explained, lawyers

20 Nevertheless, company attorneys take no chances, as one of their numbers explained: "Judge ... is a friend of the law firm, so he was sought out for the show-cause order. However, once the show-cause order is signed, there is no further opportunity to shop for a trial judge." 
have no control over the choice of the judge to whom the action is subsequently directed:

Company attorneys do not judge-shop. It's too hard to do.

The special term judge assigns it. The only variable is:

Who is currently sitting in special term for the month?

Show-cause orders are never denied-they merely get you on the calendar.

Nonetheless, lawyers can try to time their action to attempt to be assigned to a particular judge. Thus a company attorney noted,

that [one] judge is to be avoided when seeking a labor injunction, because of [his] . . . labor background. It is not always possible to time the bringing of the case to a judge's tenure in special term.

As this attorney observed, company counsel usually does not have the luxury of controlling the timing or the action. Even so, local judges, even one with a union background, were generally perceived as fair. Other judges were primarily seen as strong advocates of peace and order. Note that these judges are elected, a fact that may lie behind these comments by a company attorney:

Judges are reluctant to enjoin in any event, because they don't want to be seen as anti-labor. ... Generally, the judge sits back and gives no initial pressure. They don't like to enjoin, unless forced to do so.

One of the biggest problems ... in the Buffalo area is trying to find a judge willing to make a decision.

First, every judge that I have ever appeared before tries to get the parties in the proper case to enter into some kind of consent order. Judges do not want to deny companies the right to do business in an ailing economy in Western New York and ... judges in Erie County do not want to adversely affect the rights of the labor organization. The judges in this county are more and more Democrat and tied to labor and are very sensitive, in my judgment, to the rights of the working man to collectively bargain his lot in life. There is no question in my mind but that they would rather not decide cases as much as have the lawyers come to a consensus on it.

Yet not all lawyers viewed judges as being open minded. A union attorney stated, for instance, that "courts here are quick to grant injunctions .... Judges feel it hurts the union less to grant than the company to refuse."

A minority of attorneys, with some reluctance, conceded that they were concerned about the judges' range of discretion:

Trial outcome in state court is not predictable. Labor lawyers don't like state [supreme court] judges-they don't have enough cases to understand the law.... The attitude toward unions by the judiciary varies from judge to judge. [Judge] . . . is tough on unions; [Judge] . . . is OK. [union attorney] 
In our district we go to a special-term judge; whoever happens to be there when the conduct you want to stop starts, you have to go to him with your application. It won't affect my strategy in the sense of judge-shopping. It may affect my thinking as the chances of being successful in obtaining the best order for my client. . . . Some judges require strict compliance of the [statutorily required pleading and proof] conditions, others don't understand it or don't care. We recently had one dismissed where there was a failure of the compliance of the conditions. [company attorney]

The union views the legal outcome as unpredictable. This case bears them out. But trial courts are perceived neither as anti- or pro-union. There is no general trend. It depends more on who the judge is. [The judge in this case] ... ruled against the union, but is not anti-union. He's just anti-make-a-decision. [union attorney]

One company attorney stated that he preferred the "letter-of-thelaw" judges rather than those who make decisions by the "seat of their pants" because the former are more predictable, thus allowing a lawyer to give sound advice to a client.

Because of these views, company attorneys representing clients who are currently being picketed are more willing to reach a private settlement. For them, not only may judges urge private resolution, but time is of the essence. In one case this pressure merged with the company attorney's acknowledgment that he sought an agreement because he felt the case was not sufficiently strong to obtain an injunction. "Initial incidents were fairly minor in and of themselves," he said. "But there was pressure from the corporate higher-ups to enjoin." The attorney went to court seeking only a settlement or stipulation, "hoping that a deal could be worked out." Despite the likelihood that no order could have been obtained, the result was a negotiated settlement. ${ }^{21}$

A second characteristic, and surely related, is the tremendous influence judges can exert on the outcome by either urging attorneys to settle or actually taking part in the settlement discussions (see Botein, 1963: 226-252; Galanter, 1985). The following excerpt from a local newspaper (Buffalo Evening News, October 12, 1976: 33) mirrors the comments of attorneys:

... [The judge conducted the] show-cause hearing, after which he refused to bar picketing, but directed the attorneys to draw an order limiting the number of pickets to 1 .

21 The first stipulation broke down and the employer against requested an order. The court, however, refused and encouraged a second stipulation, which was later followed by a third. The second stipulation was also agreed upon, even though the judge, who had not presided over the first stipulation, stated that the incidents were minor. The third stipulation resulted in a limitation on the number of picketers. Although there had been 50 picketers at each gate, the parties agreed to limit the number to 12 . According to the company attorney, this figure came from the testimony of a police officer as to "how many pickets could be controlled." 
Though the judge refused to enjoin, he issued a stern verbal warning against interference with access to the plant: "The last thing I want to do is issue an injunction, but I will if I have to. The court cannot tolerate such interference. If some hothead wants to challenge the law, he will find he has a tiger by the tail."

Although many judges were perceived as unwilling to make a decision, many were thought to be perfectly willing to enjoin unlawful actions and at least to limit the scope of picketing. The determination of what behavior violates the criminal law is made by the judge; there need be, of course, no formal criminal proceeding. Moreover, the insistence of judges on settlements puts pressure on a union and its counsel to discount the union's rights. In one case, for instance, the company returned to court seeking a new order after a private stipulation had broken down. The company alleged that the union had violated the stipulation daily by blockading and assaulting exiting vehicles. A private company guard was reportedly attacked, and the police had taken forty-five minutes to arrive after the incident. Nevertheless, a company attorney reported,

The judge recommended a second stipulation, rather than a hearing. The parties agreed to try it again. The judge set up a conference with all parties and lectured the company and union representatives to respect the stipulations. He seemed reluctant to issue an injunction-the incidents were minor, no real personal injury, property damage was minor. The stipulation had merely broken down. Thus a second stipulation was urged, reflecting the judge's reluctance to formally act.

Importantly, the union consented to the judge's recommendation even though it believed there was no basis for an injunction. Thus, although attorneys did acknowledge the unpredictability of judicial decisions, they simultaneously affirmed the general predictability of judicial behavior. Whether via benign neglect or affirmative intervention, courts avoid imposing formal decisions and encourage either private settlement or agreement on the scope of a judicial order.

\section{The Appellate Courts}

The parties to such cases, although repeat players in Galanter's terms (1974: 97-104), generally do not appeal or seek "clear rules." The basic reason, as these union attorneys explain, is that appeals take too much time and money:

Appeals are never contemplated. It has never come up. There is no time to think about it-the cases arise too quickly. It would be nice to be able to have papers which are better written and which might take into account possible appellate results, but it just never happens. There is not time.

The appellate outcome is not looked to-it's too remote in 
time. . . . It certainly was not considered here, nor [have I] ... ever done it elsewhere.

Even company attorneys realize the impracticality of appeals:

Appellate action was never in mind. The case was too close to settlement of the contract. Appeals are costly and time-consuming. Small unions can't afford it.

A union is thus different from many other types of repeat players in that it is both a democratic organization and one often possessing limited funds. This situation frequently forces a union to eschew principle for pragmatism. Repeat players may have significant differences in political and economic power that in turn affect both their relationship and their relationship with their clients. ${ }^{22}$ Pressures of time and money, then, tend both to encourage settlements and to discourage appeals.

Appeals, moreover, take time and, while a decision may aid in future disputes, vindication in the current conflict may come too late to be perceived as worthwhile. Timely group action is crucial, especially given the institutional problems of attempting to reinstitute and reinvigorate group action that has been delayed. Thus, although the parties may abstractly value the existence of clear precedents or rules, the situation may militate against the effort to obtain them. ${ }^{23}$ Finally, the value of legal precedent may be limited to the unique factual situation of a particular case. As a result, negotiation is apparently perceived as a rational response. Since a judge may totally or partially prohibit picketing, unions pursue a "mini-max" strategy, agreeing to a limitation on the number or location of picketers as a sensible alternative to the risk of maximum restriction of picketing.

The lack of appellate involvement has at least two effects. First, while the actual decisions of appellate courts may seem relatively unimportant, their absence affects litigant behavior. Lacking appellate decisions that instruct the trial judges, attorneys

22 Although, as Galanter (1974) notes, the repeat players/one-shotters categories do not exactly parallel the "haves/have nots" line, there is some overlap.

23 In the over 4 decades following the passage of section 807 of the New York labor law, only the Mays, Busch, and Ballis cases involving the enjoinability of picketing on a finding of violence under the statute have reached the New York State Court of Appeals, the state's highest court. Once injunctive relief is granted by the trial court, appellate review is limited to whether the trial court findings are sustained by the evidence. See May's Furs and Ready-to-Wear, Inc., v. Aaron Bauer, 282 N.Y. 331 (1940); and Busch Jewelry Co. The court of appeals has shown reluctance to set aside the equitable relief granted. In Busch Jewelry Co. (at 157), for instance, the court indicated that "where such an injunction has been granted (a section 807 injunction), this court may not interfere except for manifest abuse."

Generally, in appellate courts, as in federal courts, reversals only occur when the appellate court determines that the injunctive relief granted was clearly overbroad in scope, which usually means that the trial court enjoined all picketing without a finding that peaceful picketing was impossible. See, e.g., May's Furs; and Abou S. Ballis v. George Fuchs, 283 N.Y. 133 (1940). 
must deal with what they feel are unpredictable trial judges. Moreover, although the possibility of appeal may be hypothetical because settlement in some form is generally reached, the doubtful value of an appeal may itself encourage settlement. Thus, most union attorneys agreed with the following assessment by one of their colleagues:

Appellate case law was not considered when preparing this case. The chances of appeal are too remote. Certainly case law is reviewed in general research, but the effect will never be tested because we never get to appeal.

Second, the lack of appellate decisions affects the law that is perceived to exist. Both union and company attorneys believe the statute is clear (even though they also often see judicial resolution as unpredictable), although they may disagree on the actual "clear" meaning. The attorneys claimed, for instance, that they knew the meaning of "violence" within the statute even though there are few clear guidelines, decisions reveal very divergent judicial perceptions, and limited research and preparation time tends to give attorneys little opportunity to evaluate the situation. This attitude is represented by the following statement by a company attorney:

As for predictability of trial results, there may be variance between judges, but no judge condones violence. Milling around for fifteen minutes is not enjoinable conduct in the local courts. The predictable aspect is that if there is serious violence, there will be an injunction issued. And these injunctions work-the scene cools down immediately.

Accommodations are made and trade-offs certainly occur, but the law is not used to clarify future interaction. Clear rules, however, may be thought to be less beneficial than a quick and relatively inexpensive settlement or even an injunction that the parties feel will not threaten basic principles. Moreover, if unions feel that violence exists, clear rules may actually provide unwelcome precedents. For employers, clear rules may not be needed because the process works to provide results that are reasonably satisfactory. The lawyers use the law to encourage more harmonious relations. An injunction or settlement "cools down" the scene even though the basic dispute continues. Moreover, the resolution of the picketing dispute may even aid in resolving the underlying economic dispute.

\section{The Lawyers}

The settlement of injunction actions is similar to collective bargaining: Intersecting interests, but not mutual interests, lead to settlement. The interests of the lawyers, or what I have referred to as the "lawyer community," intersect in a number of ways.

Lawyers have developed a sense, although not really a definition, of violence within the statute, and they have developed mech- 
anisms to process injunction cases. Union lawyers reported that they "knew" when such violence occurred, even though both case law and their experience with these cases were limited. A review of the small number of reported decisions would lead one to conclude that the statutory definition of violence was potentially ambiguous. In fact, however, the lawyers behave, or say they do, as if the law were indeed clear.

The "clarity" seemed to be based upon implicit standards created by, and seemingly shared by, attorneys on both sides. Union lawyers, for instance, said they often relied upon the good faith and professionalism of company attorneys in seeking injunctions in the first place. Thus, in theory attorneys did not need to seek clear rules, at least on this issue, for they had created them, albeit implicitly. ${ }^{24}$ To avoid the perceived unpredictability of judicial behavior, the lawyers created standards and developed a process for settling these disputes. Judges were at most wild cards that were best avoided.

The norms of the legal community define certain acceptable modes of behavior. Thus, union lawyers are not expected to stand on their clients' rights and assert the full protection of the statute. One young attorney representing a union refused to reach a private settlement, opting instead for the statutory hearing. He was informed by the company's attorney that, given his youth, he obviously "did not understand the process." Similarly, a company lawyer criticized an out-of-town employer's attorney who sought "too much." Young attorneys need to be socialized into community norms, and out-of-town attorneys can be expected to be ignorant of local norms.

Moreover, local company attorneys are expected to act reasonably and not seek unjustifiable injunctions. As could be expected, company lawyers stressed their good faith in bringing injunction actions. One company lawyer, for instance, believed he could have obtained a total injunction in one case but only sought a numerical limitation of the number of pickets:

We will only go into court when absolutely necessary. We don't go in to harass a union or impress our client. We won't make a mountain out of a molehill ... [because] this hurts labor relations. By going into court only when necessary, we preserve the effect of court action.

Bad violence is what we wait for; serious violations of the criminal code. We won't go in for libel and slander, even if the company wants it. Nor will we go in on disorderly conduct. Dirty names aren't enough. The union thinks less of the employer who runs right to court for lit-

24 Yet in most of the cases for which employer pleadings and affidavits were obtained, acts were alleged that, if they had actually occurred, would be characterized by most people as "violence." Thus whatever the lawyers actual definition of violence, it was not an operative factor in these cases. 
tle things. Minor incidents are part of the strike and the courts will not be moved by their occurrence.

Such activities, however, as blocking passage, damaging vehicles, creating obstructions or dangerous situations where people may get injured, are serious enough to seek to enjoin. Also, if there is a critical need to get supervisory staff through a gate to keep the plant operating, we will seek to enjoin conduct which prevents passage.

I will never seek total ban on picketing, because people have a right to picket and to seek a zero limit would be contrary to what I feel is right.

Another employer counsel emphasized the care exercised in creating the proof needed to seek restrictions on picketing:

The company hired a private security firm which was briefed by the lawyers on what to look for: blockading, massed picketing, and damage to persons and property. The guards were told to keep a detailed log on the number of pickets, their activities, and any incidents. For identification of perpetrators, cameras were given to the guards. The guards were further instructed to call the police if trouble occurred, and to record what the police did.

This lawyer stressed the serious costs of the failure of an attempt to obtain some kind of limitation: "To litigate in a case like this, the company must have a very strong case, because if it loses, the violence is seen as being condoned."

Union lawyers often expressed their confidence in the good faith of company lawyers, a perception that may affect and be shared by the judges and help to nurture the legal culture:

Trial outcome is not unpredictable if you have the facts.

Because we don't go to court often, most local judges presume that if you're there you have something.

Yet company action was sometimes motivated by client pressure, as one company lawyer explained:

Initial incidents were fairly minor in and of themselves. But there was pressure from the corporate higher-ups to enjoin. Other [company] plants nation-wide had obtained injunctions, and national management pressured the Buffalo plant to get an injunction too.

Prior to going into court the first time, [the company attorney] ... spoke with the union attorney to get his view. I went to court hoping a deal could be worked out, and saw that it could. The company wanted an order; the union wanted a stipulation. They compromised with a signed stipulation, with a possible injunction if it was violated.

I did not feel I could have obtained an injunction at this first court appearance. Police response to date had been adequate, and therefore trial would have failed. So I went looking for a stipulation [emphasis added].

Although this statement suggests that union attorneys should not be so confident about the validity of employer claims, the case may 
be an anomaly as the firm was one of the few national companies involved in this study.

Another company attorney stated that in one case he "asked for the world" and received more than he expected. As in some other cases, the employer requested damages, in this instance compensatory and punitive. In addition, the use of "canned" or previously used bills of particulars by some company counsel raises some question about the confidence often expressed by union attorneys in the good faith of their adversaries.

Nevertheless, the small number of lawyers and the absence of known "union busters" obviously help create a fairly cooperative atmosphere in the legal community of Buffalo, which may be uncommon in the United States as a whole and probably does not exist in larger cities with a bigger labor bar. As one union lawyer said,

[The local management lawyers] ... have never ... consciously misrepresented anything to me. Western New York is rare: The labor lawyers know each other, have mutual respect, and are very practical, looking always for practical solutions. The personal respect between attorneys in a small labor law community helps to achieve practical results and is one reason for so few actual trials.

\section{THE CALCULUS OF SETTLEMENT AND THE TRANSFORMATION OF DISPUTES}

\section{A. Settlement Incentives}

This study describes a legal community that has developed well-defined norms of behavior. In addition, institutional and community needs affect the advice that both company and union lawyers give their clients.

Labor and company lawyers have common or at least intersecting interests. One convergent interest is the avoidance of judicial discretion. Judges, often seen as unpredictable interpreters and implementers of formal law, are to some extent outsiders, at least to the zone created by the intersecting interests of company and union lawyers. The legal community has sought an accommodation that attempts to lessen the possible unpredictability of judicial action by settling proceedings, as several union lawyers expressed:

It was to union's advantage to consent, because a trial might be lost and bring more restrictions . . . .

The only thing we gave up was the number of pickets. Might as well consent rather than try it and get the same thing. A trial would therefore not be worth it.

The company filed a long bill of particulars. A trial was not worth it. The client didn't want a trial just to dramatize. There was no advantage in not settling. We could 
earn more fees litigating, but the end result would be an injunction. So we forewent a hearing and settled for a consent order [actually, a stipulation]. Had the case been tried, the union would have been enjoined.

This case was settled because of the likelihood that the court would issue a temporary injunction. The alternative was to settle it in what may be more advantageous terms than what the court would do.

It is possible to see the police (and perhaps even the clients) as "outsiders" as well, whose interests must be accommodated and controlled so as not to upset the overlapping concerns of the lawyer community. 25

Many of the judges involved in the cases studied tried mightily not to act at all, whereas others participated actively by encouraging settlements. Both types of behavior, however, tended to lead to negotiated settlements. It is difficult for lawyers to resist judicial encouragement to settle, and attorneys understandably are reluctant to stand on procedural or substantive rights in the face of judicial pressure. In this sense, judicial behavior was fairly predictable. Indeed, the settlement-prone behavior of lawyers makes it less likely that judges will have to apply the statute.

Similarly, because both sides are interested in avoiding some of the risks of rank-and-file militancy, judicial restrictions on picketing may also serve some institutional interest. ${ }^{26}$ Some union lawyers said (and some employer attorneys concurred) that their clients saw injunctions as a way of containing militants and "hot heads" who, union officers feared, could not be controlled in the absence of a court order or at least an agreement:

To say a union welcomes an injunction is inaccurate. ... A stipulation in lieu of trial is helpful because additional costs are avoided. It helps a union gain control of its own members via a constant number of pickets. . . But it's not really "welcome"; it avoids higher costs.

A limitation would ease the burden of the leadership. Younger workers were drinking on the picket line. A limitation was desired by the union to enable it to control these members.

And unions do welcome an injunction in cases such as this

25 This notion was suggested, with characteristic acuity, by my colleague David Engel.

26 Picketing itself may serve institutional interests, as one company attorney suggested:

There were prior strikes at [the company] . . . but none so hot as this one. The union did not attempt to negotiate. All knew mass picketing was illegal and would be enjoined; but the union was desperate, and angry about the replacements. "Let the court do it," they said. The union was demonstrating its will to resist. The court gave the company no greater relief than would a settlement, so there was nothing to lose; picketing would be limited in any event. 
to control feisty membership. Such was the case here. The violence was hurting chances of settling the strike.

Initially, it may not be clear how a private stipulation or settlement, basically a contract, could serve this control function. ${ }^{27}$ Apparently to increase this control function, agreements were sometimes signed by the judge, making it possible to publicize the agreement as an injunction. Lawyers conceded that the judicial signature was only "symbolic," but symbols have real effects, and the parties' behavior seems to reflect the accurate perception that injunctions are powerful vehicles for compliance.

Unions often had an additional, very practical reason for settling and avoiding a hearing. First, if picketing occurred in winter, securing picketers was often a problem in a city whose climate is not always temperate. If, for instance, only three persons could be expected to show up to picket in any event, there was little reason to struggle to pressure for the abstract right for more than three to picket, especially if some limitation was likely to be approved by the judge. A number of union attorneys acknowledged this fact:

[The] . . . company must show it [a limitation] to be necessary. But union never had enough pickets anyway, so a limit didn't hurt.

I consented to the order and numerical limitation out of practical considerations. The other unions wanted it. And mass picketing aside, it would have been hard to get ten pickets on the line at this point. Had we gone to a full hearing, the company probably could have obtained an injunction.

The union was interested in limiting the number of pickets in this case for two reasons: First, the blizzard weather made large-scale picketing difficult to maintain. A limitation would ease the burden of the leadership. Second, younger workers were drinking on the picket line. A limitation was desired by the union, to enable it to control these members.

Employers who believed that the conditions of the statute entitled them to an injunction were willing to settle for less because of both the uncertainty of a judicial determination and the costs of delay. The statute requires a full hearing and the taking of evidence on each statutory condition. This takes time, which means that the union activity will go unchecked for a longer period (assuming the injunction will ultimately be granted) and that greater legal expenses will be incurred. As one company attorney noted,

Despite how fast I might be in getting my paperwork out, it is still going to take a day to get it out. Despite how aggressive I might be in trying to get a judge to sign an order to show cause, it is going to be a day plus to get that

27 The agreement could be said to reflect the "least bad" result, with an injunction to follow if violations occurred. 
done. ... [T] [Te union is by virtue of the rigors of [section] 807 entitled to close my client's plant for a period of at least two days.

Thus, the existence of the statute itself provides constraints for employers, encouraging a move to some middle ground.

Unions too, particularly small local unions or ones with limited funds, are troubled by the further litigation expenses required for a hearing, as their lawyers revealed:

This union is financially troubled and could not afford a protracted hearing ....

The union did not seek a full hearing because it had no money to pay a lawyer's trial fees. This influenced it to seek the stipulation.

In one situation the union attorney was ready to try the case, believing the company would only call one or two witnesses, "but then the other side hired an of-counsel attorney, who promptly subpoenaed twenty to thirty witnesses and union members to testify." Because of this, the attorney "went in looking to negotiate."

The costs imposed by bad publicity also encouraged settlement:

We would have looked bad-there were some incidents provable. Even if we'd won in a trial, some of our members would have had to take the Fifth, which would have looked bad in the press. Bad press would hurt negotiations and would also affect the judge in a trial. So the idea was to protect union members from trial. Keeping press out was more important than vindicating legal rights here. Press affects court and negotiation. [union attorney]

In papers, and in brief argument before Judge . . ., the company pointed out the public impact of the union's violent activities. The chambers conference which followed resulted in a stipulated injunction, signed by the court, limiting the number of pickets, and barring certain other activities said the union caved in to avoid PR problems. It gave in on everything to avoid the bad publicity of its acts. [company attorney]

Doubts about what judges will do, when combined with the pressures on company lawyers to get some kind of limitation and the institutional interests of unions, play a role in the high number of settlements of injunction actions. In some cases, the unions may receive a windfall because a formal order could have been more severe. On the other hand, such limitations, prior to the statutorily provided hearing, may represent a surrender of statutory rights.

The community definition of violence under the statute may reflect an accurate prediction of what trial and appellate courts would in fact find. Yet in cases where the evidence was more doubtful, unions and their attorneys acted in a similar manner. The explanation seems to be based less on a sense of unease over the possible judicial reaction or jointly shared definitions of vio- 
lence than on the perceived benefits of resolving the dispute quickly and in a way that minimized costs, adverse publicity, and conflict.

\section{B. The Nature of the Settlement}

What begins as a dispute about the union's right to picket is transformed into a negotiation that centers on the location and number of picketers that will be allowed. By reducing but not eliminating picketing, both parties can avoid an all-or-nothing outcome that would be unacceptable to either party.

The number of picketers permitted as the result of negotiation or judicial order was influenced by at least two factors. First, the number of picketers desired or agreed upon was somewhat related to the number of pickets actually present. Second, there was a tendency to split the difference between union and employer requests, a not surprising result when a range of possible outcomes exists.

In one case a limitation was reached by consent after negotiation in chambers. The company lawyer noted that the number was arrived at by considering the number of strikers (14 were usually present), the width of the gates, and the fact that the company had no full-time security force. In another case the police witness provided the critical testimony.

The court recessed and removed to [the judge's] chambers. There was some talk at the outset of a TRO [temporary restraining order], but this was nixed by [the union's attorney] ... as a matter of law. The parties achieved a third stipulation instead, limiting the number of pickets to twelve. .. . How was the number arrived at? There had been fifty at each gate, followed by mass picketing. The number twelve came from the testimony of the police witness as to how many pickets could be controlled. There was not much numerical negotiation. The number was agreed upon by all. [company attorney]

The main issue in these kinds of cases is the number of pickets. The rest of the orders usually ban conduct which is already illegal, i.e., no violence, physical threats, etc. Ten to fifteen pickets per gate is a good number, according to unions. It allows them to be seen and to hassle traffic. In [this case] ... there were upwards of fifty pickets before the stipulation. Reduction to twelve was good for this reason. [union attorney]

The parties offered numbers, the judge picked a middle figure. [union attorney]

When numerical limits are sought, the union response is that numbers don't matter, rather it's what the pickets do which is important. But there is never a lengthy argument over the number. It's more a matter of what they do on the line. The issue is never exhaustively argued or briefed. 
It is not a big hang-up. The judge never even has to decide-because the parties can usually agree. [company attorney]

In my point of view, I go in with the view towards trying to get the maximum distance with the fewest number of pickets consistent with our people being able to go in without any delay. That is not to say that that has to be accommodated by my client and in my [view] . . . they have the right to be there. To say, for example, they are entitled to have eight or ten people walking between the posts of a thirtyfive-foot gate is one thing, but to say that they would be entitled to thirty people there walking between the posts of a thirty-foot gate would mean that they would essentially be a foot apart walking two-by-two. There is no way in the world you would drive a car through that. One of the things, for example, I try to calculate the distance between them that will allow for a car to pass between them without a great delay or difficulty. It depends on the width of the gate. It also depends on their ability to advertise their agreements in the areas approximate to the gate without necessarily creating a parade within the gate area. [company attorney]

Thus the use of judicial power to restrict the scope of labor's economic weapons is transformed into a dispute about numbers.

\section{Transforming the Nature of the Issues}

It is useful to view these events in terms of the lawyer's role in transforming disputes of value into conflicts of interests (Aubert, 1963). The picket line represents one of the union's basic strengths, and an injunction has historically been seen as the assertion of state power to infringe basic human or collective rights. ${ }^{28}$ Furthermore, those rights are enshrined in the NLRA. The protection of the right to picket thus involves deeply held union values, the kind that seemingly could not be compromised (Mather and Yngvesson, 1981: 778-780, 788-797). But the problem is more complex, for the picket line is not the conflict-not the dispute-even for the employer. Rather, the picket line is a weapon in a broader conflict over working conditions. The receipt of an injunction strengthens the employer vis-à-vis the union in this economic contest, just as the existence of a picket line is a vital weapon of economic leverage for the union.

The battle over the injunction, then, is an element of a wider struggle. The state and federal anti-injunction laws, which involve only a part of the dispute, attempt to remove the state from interfering with this economic contest. The existence of violence, the

28 Employees commonly believe that the number of picketers is important either for self-protection or to carry out a function that is concededly unlawful, that is, to block the gates. Although it is rarely commented upon, picketing also has the valuable effect of giving strikers something to do while temporarily unemployed. 
adequacy and availability of the police, and the employer's compliance with statutory pleading and proof requirements are not the subjects of the underlying economic dispute. That dispute, consistent with American ideology, is seen as a private dispute to be resolved by relative bargaining power. The fight over the existence and scope of a picket line is of course directly related to the alignment of economic power. In this sense, some of the questions in the injunction proceeding, especially over the numbers and location of allowable picketers, are directly related to the underlying dispute. In addition to the economic effects, the number of picketers also displays collective strength and involvement of the union. For the reasons stated, however, this economic battle, insofar as the picket line is concerned, tends to be settled by an agreement on the number of pickets to be allowed. Thus if the parties can focus upon the number and location of picketers, a dispute of value can be transformed into a conflict of interest and settled prior to a judicial ruling.

The employer desires an injunction because of the economic effect of picketing, although some employers do seek only a numerical limit on picketers, as one company attorney explained:

There were two purposes in seeking a numerical limitation of picketing. First, to reduce tensions and save money spent on security at various company installations. Second, to stop the violence.

Coming up empty-handed may affect the economic or emotional balance of forces. The union, for its part, wishes (generally) to avoid an injunction or even a numerical limit. Yet if pressures to settle exist, the only focus can be on the number of picketers. And, indeed, this is where settlement tends to occur. The employer can claim a victory, one that can be transmitted to company official or stockholders, especially since the written law seemingly makes it difficult to obtain an injunction. The union, on the other hand, can settle, avoiding additional legal fees, without seeming to have conceded on an issue of value. As one union lawyer perceptively noted:

The client union does not perceive negotiation [in a picketing injunction case] as a surrender of statutory rights. But it is a surrender of principle. The union chief is accountable to membership. He convinced the union to picket; a settlement to eliminate picketing takes that away; better to risk losing all than to look like a compromiser in front of his own men. However, the usual numerical limitation presents no problem. The pickets are still on the line. There are no internal problems then.

The role of lawyers is of course crucial. Lawyers assist their clients in employing or avoiding the imposition of restrictive formal law as well as in "transforming" the underlying economic dispute into statutory issues. But prior to the application of formal 
rules, lawyers can be said to transform the dispute again by focusing upon tactical matters such as cost of litigation and delay and the likely or unpredictable nature of judicial behavior. Lawyers play a central role because settlements and consent orders help to diffuse volatile situations. ${ }^{29}$

Highly volatile situations are created when companies attempt to operate during strikes. Closing is often a matter of managerial discretion, and the decision to remain open means that nonstrikers, distributors, truck drivers, and even replacements may attempt to cross picket lines, thus weakening the economic impact of the strike. Tensions arise from the irritation employees feel when the workplace remains open during a strike.

Lawyers generally agreed that the filing of an injunction petition was primarily an indication of an employer's intention to remain in operation during a strike. The injunction or settlement helped to diffuse emotion, but worker anger stemmed from the employer's initial decision to remain in operation. ${ }^{\mathbf{3 0}}$

A company trying to keep shipping over a strike usually needs an injunction. If the company is forced to shut down, no injunction is required because the union pickets are less tense. In this case, incidents picked up when the union saw the company was continuing to ship goods in and out. [company attorney]

Where a plant remains open, strikers are irritated. In this case, the independent truckers stirred things up. Supervisors had been running the plant, too. In this kind of case, problems are more serious on the picket line. Yet, section 807 does deter injunctions. Judges don't want to be policemen. The Penal Code rules can be as easily applied. [union attorney]

Nevertheless, attorneys reported they were generally unaware of the actual effect of an injunction or an agreed upon stipulation. Although company attorneys felt "an injunction is a great moral victory and hurts a strike," few cited any concrete effects of the injunction action and its resolution. ${ }^{31}$ This may result from the often limited involvement of attorneys in economic disputes and obviously reveals the shortcoming of a study focused only on attorneys. One union attorney noted that court intervention and limitation might have a demoralizing effect on strikers, but he did not feel the cost to morale was as great today. Attorneys generally did

29 This formulation was suggested by Lynn Mather.

30 The ability to stay open during a strike is considerably enhanced by the U.S. Supreme Court's decision permitting the permanent replacement of strikers: NLRB v. Mackay Radio \& Telegraph Co., 304 U.S. 333 (1938); see Atleson, 1983: chap. 1.

31 Since the picket line is only one weapon in an ongoing economic contest, it would be difficult to "isolate the influence of injunctions from other factors which may have had a part ..." (Witte, 1932: 120-122). 
feel, however, that injunctions "cool down the situation immediately." One company lawyer said,

I think what they like to do with the least amount of interference with the right to peacefully picket, they want to allow the thing to settle-to quiet the thing down. That's the point of most of the injunctions I have seen granted. It is not to clobber one side or the other to create an advantage for one side or the other in the process.

The result of negotiated settlements to the union is, at least in the abstract, a diminution of its collective strength, although constraints also push employers to seek less than a judge might grant. The "middle ground" toward which pressures direct both parties may constitute a discounting of employee rights. Unless it could be said in every case that the employer would be successful, the pressures toward settlement are not necessarily neutral in impact. Nevertheless, parties often have mutual, or at least intersecting, interests in seeking to limit the effects of conflict.

To union lawyers and their clients, union officers, picketing may often be less important than one might believe. Militance on the picket line is not necessarily shared by the union's leadership. The settlements, though, do not necessarily reflect a lessened militance or valuation of picketing, for what unions concede is not technically the right to picket but rather the unilateral right to determine the number and locations of picketers.

Picketing is primarily designed to notify the public, nonstrikers, and replacements that a strike is in progress. When this is so, the number of picketers may not be a crucial factor. Certainly union lawyers seemed to view the situation through this instrumental lens. Historically, however, unions have viewed the number of picketers as important, either for actual or perceived self-protection. If one purpose of picketing is to build or display group solidarity and morale or to cause economic disruption even for a short period, the number of picketers would also seem to be important. Whatever the precise purpose or purposes of the picketing in these cases, however, unions were routinely willing to subject the issue of the number and location of picketers to negotiation rather than permit a judge to make this determination.

The situation might be different if the union perceived that the stakes were higher. Thus if the very life of the union were threatened, or if the union thought the employer was trying to destroy it, the union might be unwilling to waive procedural rights, such as the statutory hearing, if for no other reason than to maximize the economic cost to the employer prior to an injunction. In less extreme situations like those studied here, attorneys were able to produce settlements despite evidence of high emotion and even violence as alleged in employer petitions. 


\section{CONCLUSION}

This study has been an inquiry into legal culture. Lawyers in picketing injunction cases represent clients in situations of great emotion and immediacy who nevertheless must continue to deal with each other on a day-to-day basis. Similarly, the small group of labor lawyers regularly interact with one another and depend on their reputations for trustworthiness and reasonableness. The lawyers strive to create predictability and to transform conflicts of values into disputes of interests so that volatile situations can be diffused quickly and resolved.

Although these lawyers never characterized themselves as mediators, the behavior they described-seeking settlements and "cooling-out" situations of conflict-is consistent with that role. Issues of principle are changed into conflicts of interests, narrowed by the explicit statutory boundaries and the implicit norms created by lawyers, so that settlements occur. It is clear that such an approach offers substantial benefits to attorneys and their clients and that attorneys are generally comfortable with a mediated form of resolution. The remaining questions, ripe for study, are how clients perceive the method of resolution and what costs are imposed by informal compromise in the shadow of uncertain judicial behavior.

\section{REFERENCES}

AARON, Benjamin (1964) "Labor Injunctions in the State Courts-Part I: A Survey," 50 Vinginia Law Review 951.

ASPIN, Les (1970) "A Study of Reinstatement Under the National Labor Relations Act." Ph.D. Dissertation, Massachusetts Institute of Technology.

ATLESON, James (1985a) "The Circle of Boys Market: A Comment on Judicial Inventiveness," 7 Industrial Relations Labor Journal 88.

(1985b) "Reflections on Labor, Power and Society," 44 Maryland Law Reviewo 841.

- (1983) Values and Assumptions in American Labor Law. Amherst: University of Massachusetts Press.

AUBERT, V. (1963) "Competition and Dissensus: Two Types of Conflict and Conflict Resolution," 7 Journal of Conflict Resolution 26.

BERNSTEIN, Irving (1960) The Lean Years: A History of the American Worker. Boston: Houghton Mifflin.

BOTEIN, B. (1963) Trial Judge. New York: Cornerstone.

FRANKFURTER, Felix, and Nathan GREENE (1930) The Labor Injunction. New York: Macmillan.

GALANTER, Marc (1985) “ ‘ . . A Settlement Judge, Not a Trial Judge:' Judicial Mediation in the United States," 12 Journal of Law and Society 1.

- (1974) "Why the 'Haves' Come Out Ahead: Speculations on the Limits of Legal Change," 9 Law \& Society Review 95.

GALENSON, Walter, and Marjorie SPECTOR (1942) "The New York LaborInjunction Statute and the Courts," 42 Columbia Law Review 51.

GREGORY, Charles (1961) Labor and the Law. New York: Norton.

MACAULAY, Stewart (1966) Law and the Balance of Power: The Automobile Manufacturers and Their Dealers. New York: Russell Sage.

(1963) "Non-Contractual Relations in Business: A Preliminary Study," 28 American Sociological Review 55. 
MATHER, Lynn, and Barbara YNGVESSON (1981) "Language, Audience, and the Transformation of Disputes," 15 Law \& Society Review 775.

MNOOKIN, Robert H., and Lewis KORNHAUSER (1979) "Bargaining in the Shadow of the Law: The Case of Divorce," 88 Yale Law Journal 950.

POPE, James G. (1984) "The Three-Systems Ladder of First Amendment Values: Two Rungs and a Black Hole," 11 Hastings Constitutional Law Quar. terly 189.

ROSS, H. L. (1970) Settled Out of Court: The Social Process of Insurance Claims Adjustments. Chicago: Aldine.

SEIDENBERG, Jacob (1953) The Labor Injunction in New York City, 1935-1950. Ithaca: Cornell University.

SOVERN, Michael I. (1963) "Section 301 and the Primary Jurisdiction of the NLRB," 76 Harvard Law Review 529.

WEILER, Paul (1983) "Promises to Keep: Securing Workers' Rights to SelfOrganization under the NLRA," 96 Harvard Law Review 1769.

WITTE, Edwin (1932) Government in Labor Disputes. New York: McGraw Hill.

YALE LAW JOURNAL (1982) "Note: Labor Picketing and Commercial Speech: Free Enterprise Values in the Doctrine of Free Speech," 91 Yale Law Journal 938.

YNGVESSON, Barbara (1985) "Re-Examining Continuing Relations and the Law," 1985 Wisconsin Law Review 623.

\section{CASES CITED}

Allan-Bradly Local IIII, United Electrical, Radio \& Machine Workers of $A$ merica v. WERB, 315 U.S. 740 (1942).

Abou S. Ballis v. George Fuchs, 283 N.Y. 133 (1940).

B.C. Manufacturing Co., Inc., v. Louis Reiff, 14 Misc. 2d 37 (1958).

Bridge Hardware Co., Inc., v. Hyman Horowitz, 22 Misc. 2d 914 (1949).

Busch Jewelry Co., Inc., v. United Retail Employees' Union, Local 830, 281 N.Y. 150 (1939).

Capital Newspapers Division-The Hearst Corporation v. Chester W. Vander. bilt, 44 Misc. 2d 542 (1964).

May's Furs and Ready-to-Wear, Inc., v. Aaron Bauer, 282 N.Y. 331 (1940).

$N L R B$ v. Insurance Agents International Union, 361 U.S. 478 (1960).

NLRB v. Mackay Radio \& Telegraph Co., 304 U.S. 333 (1938).

Triangle Finishing Corp. v. Textile Workers Union of America, 145 N.Y.S.2d 614 (1955).

$U A W$ v. WERB, 336 U.S. 245 (1949).

UAW v. WERB, 351 U.S. 266 (1956).

Waldbaum, Inc., v. United Farm Workers, AFL-CIO, 87 Misc. 2d 267, 269 (1976).

Youngdahl v. Rainfair, Inc., 355 U.S. 131 (1957).

\section{STATUTES CITED}

National Labor Relations Act of 1935 (ch. 372, § 1, 49 Stat. 449 (codified as amended at 29 U.S.C. § 141 et seq. (1974)).

Norris-LaGuardia Act of 1932, 47 Stat. 70 (1932), 29 U.S.C. $\S 101-115$.

N.Y. LAB. LAW \& 807 (McKinney, 1977). 